\title{
Learning Independence of Students at Dayah Muslim School in North Aceh
}

\author{
Zulfikar Ali Buto ${ }^{1}$, Hafifuddin ${ }^{1}$ \\ ${ }^{l}$ Faculty of Tarbiyah and Teaching, Institute for Islamic Studies (IAIN), Lhokseumawe, Indonesia \\ zaulelsm@yahoo.com
}

\begin{abstract}
Learning independence of students at Dayah muslim school in North Aceh through various activities of Dayah in an effort to make Dayah's Alumni who are ready to adapt and continue life in society. Various activities carried out are structured, so the control and evaluation are carried out periodically. The independence of Dayah's student in the present context will experience difficulties when the necessary of the times keep developing. If the student are not ready, they will experience being overwhelmed to face global competition. This research aims to find out and describe the learning process of the independence of Islamic boarding students, especially those in the North Aceh area. This research uses a qualitative research approach with with a phenomenological approach that is descriptively qualitative. The results show student education of Islamic boarding school in North Aceh can be described through several fields, such as students' independence in doing ubuduyah, students' independence education in recitation activities, independence education in carrying out social activities, students' independence education in developing economy through another skill.
\end{abstract}

Keyword: indenpence; student; dayah

\section{Intorduction}

Learning is assistance provided by educators so that the process of acquiring knowledge can be occured, mastery of proficiency and change, and the formation of attitudes and self-confidence of students. ${ }^{1}$ In other words, learning is a process to help students to learn well in accordance with the given currriculum. Learning has a similar understanding of teaching although it has different connotations. In the context of education, teacher learning is directed at the development of students to be able to learn and master the contents of the lesson to achieve a determined objective (cognitive aspects), can also influence changes in attitude (affective aspects), as well as skills (psychomotor aspects) of a student. ${ }^{2}$ The teacherdirected learning process refers to the strengthening of cognitive, affective, and psychomotor aspects which are intended to develop students' self-reliance (santri) so it can be the life grip of the students in the future.

The independence of student is an attitude thai is gotten during development where individual will keep studying to be independent to face various situation in society which in the end they are able to think and act by themselves. Independence can develop student more steadily. to be independent, someone needs opportunities, support, and encouragement from family, teachers, and the surrounding environment. In order to achieve autonomy over

\footnotetext{
${ }^{1}$ Sagala.Syaiful, Konsep Dan Makna Pembelajaran (Bandung : Alvabeta, 2007), p. 62.

${ }^{2}$ Sanjaya, Kurikulum Dan Pembelajaran (Jakarta: Kencana, 2008), p. 216.
} 
oneself. The role of family, teacher, and the surrounding environment can strengthen each behavior carried out ${ }^{3}$

Sustainability of student in the future is influenced by development of their indenpence. This case is important in throughout the span of human life. The development of indenpence is influenced by physical changes, which in turn can trigger emotional changes, cognitive changes that provide logical thinking about the ways of thinking that underlie behavior, and changes in values in social roles through parenting and individual activities.Sensitive times that are felt and forced will have a negative impact on the development of students' age. The result will be felt very important when the development of adulthood, where the spirit of independence that should be embedded in his soul is inversely proportional to dependence on others. The difficulty of escaping from the help of others causes him to be far from the spirit of independence which should lead him to readiness to face the challenges of life and time.

The support of the spirit of independence which was planted of dayah became a dilemma when the Islamic boarding school students dissolved by participating in various activities in the dayah so that the age sheet was no longer the benchmark for completing education in dayah. Following the debriefing of religion without seeing the standard of age until he settled in the dayah in decades his religious ability had reached the equivalent of teungku/abu/abi. But unfortunately, the learning in dayah paid little attention to the needs of the santri in terms of learning independence so that the scope produced by the dayah was limited to be tengku in dayah or balee in which he founded after the return of his studies at dayah-dayah. During their stay at the Islamic boarding school the students of the Islamic boarding school dissolved in religious knowledge forgot about their age and life needs when they left the Islamic boarding school, the scope of life was narrowed by their ability to deepen certain fields of expertise needed for social survival.

Based on the background above, it would be enough as an excuse to examine and review how the learning of the students' independence of Dayah. If not, it is feared that the main mission is to educate students to be achieved in order to sustain their lives where the future will experience difficulties to adapt and socialize with the conditions of the times that continue to develop.

\subsection{The Meaning of Independence}

\section{Review of Literature}

Independence comes from the word "independence" which is defined as a condition where a person is not dependent on others in determining decisions and the existence of selfconfidence. ${ }^{4}$ Whereas according to Sujanto independence is the ability of a person to understand the difference between right and wrong, which is permissible and which is prohibited, which is recommended and prevented, good and bad, and the individual must stay away from negative negativity and try to attend to always develop positive things. ${ }^{5}$

According to Kartono, independence comes from the word independence, which is usually interpreted as something independent, namely the ability to stand above his own

\footnotetext{
${ }^{3}$ Zainun Mu'tadin,"Kemandirian Sebagai Kebutuhan Biologis Pada Remaja", http:www.epsikologi.com, diakses 18Oktober 2016.

${ }^{4}$ Chaplin, Kamus Lengkap Psikologi (Jakarta: Rajawali Press, 1996), p. 105.

${ }^{5}$ Sujanto, Psikologi Kepribadian (Jakarta: Bumi Aksara, 2001), p. 290.
} 
ability with independence and responsibility for all his behavior as an adult human in carrying out his obligations to meet his own needs. ${ }^{6}$ Hedug says independence is a trait that allows a person to act freely, do something on their own impulse, pursue achievement, full of perseverance and desire to do something without the help of others, or think and act original, creative and full of initiative and overcome problems that faced, as well as controlling his actions, able to influence his environment, have self-confidence in his abilities himself, appreciate his condition and obtain satisfaction from his business.

Through some of these opinions, independence is the ability of individual students to run a life with no dependence on others, so that they can adapt and socialize with the local community well.

\subsection{Education of Independence}

Based on the findings in several Islamic boarding schools in Aceh, especially in North Aceh, like Dayah Lhok Nibong, Babussalam Matangkuli, Panton Labu, Darul Muttaqin Laga Baro, and so on. Independence is one of the programs to realize the direction and purpose of dayah education inspired by the five souls, as mentioned above. Because so important the nature of independence is owned by students, especially students who live far from parents. life in the dayah must be armed with independence. Independence is a condition in which a person is not dependent on others in determining the decisions of life's journey. A lot of independence wants to be developed by dayah to students daily activities of Dayah complex, starting from independent when you wake up, independent in doing prayer, independent in reciting, independent in learning (repeating), independent in memorizing, independent in interacting with others, similar opinions also expressed by Saryulis as teungku in charge of the education section at dayah Babussalam Matangkuli said that the students are educated by the independent souls. So that with the upbringing, if the soul is established and found awareness in themselves, then they will always do everything with independence, without being forced, here we strive for the santri especially independent in performing prayer, meaning santri has an awareness in carrying out these obligations, then strives for independent santri in reciting, repeating, interact with others ikhwan and also independent in carrying out other activities in their daily lives. ${ }^{7}$

\section{Discussion}

Through these findings, it was summarized that some Islamic boarding schools in the North Aceh region wanted to give birth to students who were independent in Islamic education, their intellectual fields, independent social, psychological and independent economics. The following are specific findings that will be described from various fields of independence that have been developed, namely:

\subsection{Independence Ber'ubudiah}

\footnotetext{
${ }^{6}$ Iin PujiAstuti,"Perbedaan Kemandirian Antara Siswa dari Keluarga Lengkap Dengan Siswa dari Keluarga Tidak Lengkap di Madrasah Aliyah an Nur Bululawang Malang”,Skripsi, Fakultas Tarbiyah UIN Malang, 2002 ,

${ }^{7}$ Interviewing of result with education directors Dayah Babussalam Matangkuli on pada hari Tuesday, 6 May 2014.
} 
Indenpende in Ber'ubudiah (doing worship) to Allah are students in dayah no longer Based on other people while working on various kinds of worship, such as Prayers, Fasting, and other religious services, meaning that students have an awareness to uphold prayer, because they understand that worship is an obligation that must be to Allah, and all awareness can only be obtained by the learning process (reciting). Learning the independence of santri in the field of worship in several Islamic schools in North Aceh through self-awareness for the need to draw closer to God through worship mahzha and ghauru mahzah. The awareness of the santri was born through habituation and deepening of the science of fiqh, fiqh proposals, and other supporting material so that the power of science and belief was integrated through worship (worship).

The lives of the santri in several Islamic schools in the North Aceh region were preoccupied with the area of approaching themselves to God through worship. This is illustrated through their runititas from the beginning of the sunrise to nightfall. Independence in carrying out worship has a good indicator of independence including; the santri worshiped without any element of force from various parties, the santri performed fasting circumcision Monday, Thursday, and other fasting circumcisions without having to be directed by the teachers, as well as worship shnaqah and infaq satri tended to feel themselves to infaq and shadaqah through charity boxes and other social needs such as infaq for misfortune, sickness, and so on. Uniquely special in the implementation of the independence of the prayers of the santri to stay overnight (falling asleep) in rangkang, balee and mosques besides repeating their lessons they are accustomed to performing evening prayers (tahajjud). The implementation of students carry out worship through their own awareness, by itself the indicators of self-reliance are internalized well within themselves until the alumni's future management. Their self-reliance process is certainly not instant, but it needs a process and habituation in them so that the habit merges into the necessity of being a muttaqin human. Planting independent values in Dayah North Aceh intended to be able to bring the complete soul of Muttaqin so that it becomes God's placed servant by Allah's side. Allah says in AlQuran Surat Ali-Imran: 102 as follows:

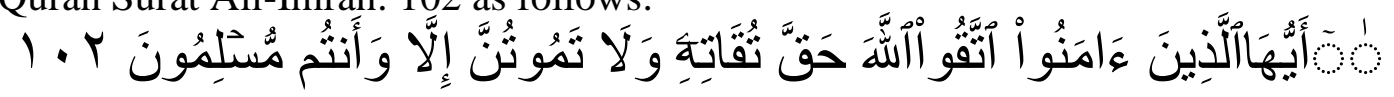

(Meaning : Believers! Fear Allah as He should be feared, and see that you do not die save in the state of submission to Allah.)

Habits that run through worship activities in the dayah, give birth to the spirit of independence of life which then gives a positive impact on the development of their individual. Actulisation of religious independence gives birth to an istiqomah spirit, maturity of the spiritual soul, psychological maturity, maturity of thinking, maturity provlem solving, maturity of the spirit of the soul, and maturity out of trouble. The spirit of peace in tidal worship is born by itself, it is necessary to make the process of habituation through habituation education coupled with the supervision and control of both internal and external self. The process of internal supervision is a key instrument in habituating itself to matters of worship, internal supervision is closer to self-motivation to carry out the values of obligatory worship and sunnah. Whereas external guardianship is closer to external encouragement to be able to support one's worship activities so that they remain and istiqomah carry out obligatory and sunnah worship. The attendees who came from outside the santri were supported through dayah regulations and policies to improve the worship of santri in carrying out the wheel of life during the dayah and were accustomed to having finished their studies in the future. 


\subsection{Intellectual of Indenpence}

Indepence in learning is a process in which santri have an awareness that learning is a must/obligation for every santri, so that santri have a high awareness of learning, so santri will always always learn, without having to be forced, willing to repeat and read themselves the book he learned, dared to ask in the learning process. Such independence will be obtained through the learning process, which is by giving the santri to the students about the importance of learning, about the benefits of learning with the millions of learning benefits contained in it.

Intellectual independence is a learning process in examining turast (classical) books both sorogan and bendongan. Dayah learning in some North Aceh regions tends to use the bendah method. The Bendongan method is a method of learning class in pesantren that positions a teacher (teuku) as a reader and guide to the book while the satri listen to and combine with the method of discussion and question and answer. This can be seen in a number of Islamic schools observed in the research locations which indicate that the dayah teungku are active as readers, directors of the books in the dayah, the tenguku read the book by occasionally explaining the science of the position of sentences in nahu and sharaf. Whereas the books of the books are carried out by Teungku by providing the broadest possible explanation, the explanation is accompanied by a contextual approach to various types of life problems both within and outside the dayah.

The knowledge and life experiences of santri make the deepening of religious knowledge and their social science to live independently increasingly stronger and accustomed. Through the excavation and deepening of the life problems of the santri, they have the readiness to deal with and solve various kinds of life problems so that the spirit of independence is born and embedded properly without having to have an element of selfimposed during life in the dayah.

The purpose of this independence is also as a forum for scientific maturity for students when plunging into the midst of society, the santri have sufficient provisions to solve religious problems that arise in the community, so that the santri can later spearhead religious development for the people of Aceh generally and for the people of North Aceh especially. In order to deepen and strengthen the knowledge of the santri dayah, they are now providing a special unit formed by the leadership of Dayah called Bahsul Masail, which functions as a place for special discussion in exploring issues and finding solutions to existing problems. Through these unit institutions, santri will be able to educate their mindset in solving various problems of life both those born in textual turast books or those born through the scope of their respective lives.

The unique information obtained from several dayah alumni was emphasized by some people that dayah alumni who had extensive scientific independence, they would return to their hometown by developing their own knowledge. Upon their return in their hometown 
they will establish small dayah-dayah and balee that are erected around the house so that their religious knowledge develops and is felt by the surrounding community.

\subsection{Social Independence}

Independence in the social field is an awareness that arises in the santri that good relations between fellow human beings (hablumminannas) is a matter that is demanded in religion, because Allah commands humans to do good to Allah, also among fellow humans, the social dynamics of the santri can already interact with each other in life and be able to maintain their respective capacities in society. The social independence education of santri in several Islamic schools in North Aceh is very good both for the development of the dayah and for the parents who deliver their children to the dayah. The social independence of santri dayah can be seen in their activeness in several social activities, including the following:

- Mutual cooperation, the Islamic boarding school students actively participate in mutual cooperation activities that are held once a week. Mutual cooperation activities on every Friday are useful in providing students with experience and participation in maintaining cleanliness, orderliness and beauty of the village around the dayah.

- Da'wah Islamiah, the participation of santri in building other self-reliance values is to participate in enlivening and becoming a participant in Islamic da'wah activities carried out by gampong. Dayah santri were trained to be organizers and lecturers in commemorating Islamic holidays such as the birthday of Prophet Muhammad PBUH, Isra'dan Mi'raj, New Year's Eve and others. Through these activities the santri can educate themselves to provide self-service to the community, the religion of the nation and the nation.

- Misfortune (facing disaster), educating and training the spirit of self-reliance of the Satri not only in the learning process that they received in the scope of the dayah, but also the practice of the value of self-sufficiency in social activities such as actively attending temple experts (dead). This misfortune activity is always a routine activity and obligatory for the santri to make a visit to Sekalikus as a priest to pray for the prayer and the prayer reader in samadiah activities (senujoh) and others.

\subsection{Economic Indepence}

Economic independence is the ability to regulate the economy and not depend on economic needs for parents or other people. The efforts carried out in the dayah to develop economic independence are by organizing dayah cooperatives which are managed by two santri or teachers in each one year period. Independent education is carried out through mutual cooperation in the development of dayah, farming such as rice, oil palm, coconut, secondary crops, etc. by the Satri, leaders or teachers. Indoor and outdoor sewing skills activities, training in electronic skills trained by experts from regional and provincial governments. With the above activities will train the entrepreneurship of students to become 
independent in the future, and students will also have reliable skills in the fields of building, agriculture, trade, and sewing skills.

The education of the independence of the santri in the dayah was very beneficial when they finished their dayah education. Economic independence through several activities such as the santri trained to grow oil palm, secondary crops, coconut, rice, and other crops has become a dayah tradition so that the santri gain life experience so that the experience becomes their future provision. The work carried out in mutual cooperation was easy and efficient so they were very happy to do it. The results obtained through farming are used as a joint result and the results are shared together to meet common needs during the study at dayah. The results obtained through agriculture provide enough relief for the santri and dayah managers so far, this is as stated by some traditional Islamic boarding school leaders in the North Aceh region who say that agricultural products that are jointly managed and worked together provide a major influence the existence of dayah. In addition to alleviating the economic needs of santri and these results are considered able to help ease operational costs such as electricity payments, book purchases, and other joint needs.

Uniquely, the independence of the santri education in several existing Islamic schools is debriefing in skill education which is a talent for ability that exists within a person so that it becomes their own expertise to support their success in society. There are several skills development of santri who are trained through their habituation and participation in managing dayah income. Skill development includes the training of sewing skills, workshop skills, cultivation skills of pods, swallow bird breeding, catfish cultivation, and others. Skill education that was born out of the ordinary was apparently a positive impact on the development of the skills of the students in the Islamic boarding school. In addition to those who study religion obtained through regular recitation, they also receive training in independent education provided through additional activities provided by dayah managers so that their spirit of independence is born and grows as expected. Besides being able to help the needs of santri and pengelala dayah, they in the future will be able to develop their own skills during their stay in the dayah. The virtues of skills acquired at dayah are very important and different from what they obtain through formal education, the skills they obtain in dayah are purely the same because of their own willingness to do and develop skills that are repellent, whereas if they are obtained through formal education, then the difficulty is the motivation to follow the support of skills development is only to fulfill the curriculum requirements, so that the funding and reinforcement obtained is limited to existing and participating in activities. So that their deepening and participation in conducting activities is very lacking and does not reach the expected goals.

\section{Conclusion}

Based on the findings of the above research, it can be concluded that the students' independence education in the North Aceh Dayah can be described through several field. The 
first, the independence of the students in carrying out ubuduyah. Secondly, their independence education in recitation or search activities and deepening of religious knowledge through the yellow books and other sciences. Thirdly, education of independent students in carrying out social activities in the fields of mutual cooperation, misfortune, other social activities and the four independent santr education in developing the economy through the development of other skills and soft skills. Through education on the independence of students dayah in the North Aceh, it is expected that these indenpendence are expected can be studennts' life grip to life in society.

\section{References}

Chaplin, Kamus Lengkap Psikologi, Jakarta: Rajawali Press, 1996

Iin Puji Astuti,"Perbedaan Kemandirian Antara Siswa dari Keluarga Lengkap Dengan

Siswa dari Keluarga Tidak Lengkap di Madrasah Aliyah an Nur Bululawang Malang", Skripsi, Fakultas Tarbiyah UIN Malang, 2002

Interviewing of result with education directors Dayah Babussalam Matangkuli on Tuesday, 6 May 2014.

Sagala. Syaiful, Konsep Dan Makna Pembelajaran, Bandung : Alvabeta, 2007

Sanjaya, Kurikulum Dan Pembelajaran, Jakarta: Kencana, 2008

Sujanto, Psikologi Kepribadian, Jakarta: Bumi Aksara, 2001

Zainun Mu'tadin,"Kemandirian Sebagai Kebutuhan Biologis Pada Remaja”, http:www.epsikologi.com, accesed 18Oktober 2016. 